\title{
PENGARUH RUANG TERBUKA HIJAU TERHADAP IKLIM MIKRO DAN KENYAMANAN TERMAL PADA 3 LOKASI DI KOTA MANADO
}

\section{EFFECT OF GREEN OPEN SPACE ON MICRO CLIMATE AND THERMAL COMFORT AT 3 LOCATIONS IN THE CITY OF MANADO}

\author{
Yordan Perwi Mala1), Josephus I. Kalangi2), dan Fabiola B. Saroinsong2) \\ 1)Mahasiswa S1 Program Studi IImu Kehutanan, Fakultas Pertanian Unsrat Manado, 95115 \\ 2)Staf Pengajar Jurusan Budidaya Pertanian, Fakultas Pertanian Unsrat Manado, 95115
}

\begin{abstract}
Microclimate is an important requirement for urban communities in creating outdoor thermal comfort. Micro climate as a benchmark in determining thermal comfort consists of 4 (four) elements which are, air temperature, air humidity, wind speed and solar radiation. Green open space area is one way to create comfortable micro climate for the community. The purpose of this study is to analyze microclimate and thermal comfort in 3 (three) green open spaces. The researcher used a purposive sampling method and chose the area with the same characteristics, namely UNSRAT Field, Tikala Field, and KONI Field. The results obtained were that the UNSRAT Field had the highest thermal comfort level with a percentage reaching $90 \%$ at $10: 00 \mathrm{a}$.m. and $80 \%$ at 1:00 p.m. In addition, the micro climates in the three locations have differences, differences occur due to canopy area, tree species, plants, pavement type and building area around green open space.
\end{abstract}

Keywords : microclimate, climate, open space, green open space

\begin{abstract}
ABSTRAK
Iklim mikro merupakan salah satu kebutuhan yang penting untuk masyarakat perkotaan dalam menciptakan kenyamanan termal luar ruang. Iklim mikro sebagai tolak ukur dalam menentukan kenyamanan termal terdiri dari 4 (empat) unsur yaitu suhu udara, kelembaban udara, kecepatan angin dan radiasi matahari. Ruang Terbuka Hijau (RTH) merupakan salah satu cara untuk mencitakan iklim mikro nyaman untuk masyarakat. Tujuan penelitian ini ialah menganalisis iklim mikro dan kenyamanan termal di 3 (tiga) Ruang Terbuka Hijau (RTH). Penelitian ini mengunakan metode purposive sampling dan memilih daerah dengan karateristik yang sama yaitu Lapangan UNSRAT, Lapangan Tikala, dan Lapangan KONI. Adapun hasil yang didapatkan bahwa Lapangan UNSRAT memiliki tingkat kenyamanan termal paling tinggi dengan persentase mencapai $90 \%$ pada pukul 10.00 WITA dan $80 \%$ pada pukul 13.00 WITA. Selain itu, iklim mikro pada ketiga lokasi memiliki perbedaan, perbedaan terjadi dikarenakan luas tajuk, jenis pohon tingkat perkerasan suatu tempat, dan kawasan terbangun sekitar $\mathrm{RTH}$.

Kata kunci : iklim mikro, iklim, ruang terbuka, ruang terbuka hijau
\end{abstract}




\section{PENDAHULUAN}

Manusia merupakan makhluk yang terus berkembang dan terus melakukan kegiatan untuk memenuhi kebutuhan serta keinginan mereka. Pemenuhan kebutuhan dan keinginan ini diikuti oleh eksploitasi dan eksplorasi terhadap sumberdaya yang ada termasuk sumberdaya lahan. Lahan yang perlukan untuk meningkatkan kualitas hidup manusia ternyata juga menimbulkan kontra terhadap lingkungan. Salah satu tempat yang menjadi per-masalahan utama terhadap lingkungan merupakan perkotaan, dengan luasan lahan yang kecil per-kotaan harus menampung banyak kepentingan masyarakat yang berakibat pada masalah lingkungan. Perkotaan mempunyai persamaan dalam masalah lingkungan seperti sampah, limbah beracun, polusi udara, polusi air serta alih fungsi lahan (Budihardjo, 2015). Kota Manado mempunyai jumlah penduduk 425.634 jiwa dan luas lahan $157,26 \mathrm{~km}^{2}$ (BPS, 2016) yang artinya kepadatan Kota Manado sekitar 2706,6 jiwa per km². Menurut Filani (2013) demi menciptakan lingkungan kota yang manusiawi untuk kesehatan dan kesejahteraan penghuninya dari masa kini hingga masa yang akan mendatang diperlukan ruang terbuka hijau (RTH) sebagai kebutuhan pokok perkotaan.

Menurut Dwiyanto (2009) ruang terbuka hijau perkotaan merupakan suatu (open space) ruang-ruang terbuka yang mempunyai manfaat ekologi, sosial-budaya dan arsitektural yang dapat memberikan manfaat ekonomi (kesejahteraan) bagi masyarakat, di mana ruang tersebut diisi oleh vegetasi. Undang-undang nomor 27 tahun 2007 mendefinisikan ruang terbuka hijau sebagai area memanjang/jalur dan/atau mengelompok, yang penggunaannya lebih bersifat tebuka, tempat tumbuh tanaman, baik yang tumbuh secara alamiah maupun yang sengaja ditanam. Menurut Joga dan Ismaun (2011) RTH mempunyai 2 bentuk berdasarkan fisiknya yaitu RTH alami dan RTH binaan. Joga dan Ismaun (2011) juga menyatakan bahwa RTH mempunyai fungsi sebagai konsrvasi tanah dan air, ameliorasi iklim, pengendalian pencemaran, habitat satwa dan konservasi flora dan fauna, sarana rekreasi dan wisata, sarana pendidikan dan pe- nyuluhan, area evakuasi bencana, pengendali tata ruang kota, estetika serta sosial ekonomi. Menurut Irwan (2008) hutan kota yang merupakan salah satu bentuk RTH memiliki 3 bentuk yaitu bergerombol atau menumpuk, menyebar dan berbentuk jalur, sedangkan struktur hutan kota terdiri dari berstrata dua dan berstrata banyak.

Unsur-unsur iklim mikro seperti suhu, kelembaban, radiasi matahari, angin sangat mempengaruhi keadaan iklim lingkungan di sekitar, selain itu ada faktor topografi, permukaan tanah dan benda 3 (tiga) dimensi serta radiasi termal dari benda-benda tertentu yang juga mempengaruhi keadaan iklim mikro (Idham, 2016). Menurut direktorat jendral penataan ruang (2008) vegetasi merupakan ke-seluruhan tumbuhan pada suatu kawasan baik yang ada pada kawasan tersebut ataupun yang didatangkan dari luar. Menurut Obi (2014) vegetasi mempunyai peran penting dalam strategi pengontrolan iklim mikro perkotaan. Vegetasi memberikan efek yang positif dalam menangani efek pengurangan suhu melalui proses penyerapan dan refleksi terhadap radiasi matahari serta efek pulau bahang serta pengurangan suhu tanah dan pengendalian kecepatan angin. Daundaun tebal yang menghalangi cahaya matahari; daun-daun tipis yang mempunyai tugas menyaring cahaya; daun dan ranting yang mempunyai fungsi memperlambat kecepatan angin dan laju curah hujan, hal ini menunjukkan bahwa semakin banyak vegetasi yang ditanam di dalam kota semakin besar manfaat untuk peningkatan kualitas lingkungan kota (Irwan, 2008).

Penelitian ini bertujuan untuk menganalisis iklim mikro dan kenyamanan termal di 3 (tiga) Ruang Terbuka Hijau (RTH). Penelitian ini diharapkan menjadi acuan evaluasi terhadap pemerintah dan pemilik lahan dalam pembangunan Ruang Terbuka Hijau (RTH) ke depan yang dapat memberikan kenyamanan iklim mikro bagi masyarakat.

\section{METODE PENELITIAN}

Penelitian ini dilakukan di Manado tepatnya pada tiga tempat berbeda yaitu di Lapangan Sparta Tikala, Lapangan KONI dan Lapangan sepakbola UNSRAT Manado. Penelitian ini dilakukan pada Bulan Agustus 2017 yang dilakukan selama 1 bulan dan dibagi pada 2 waktu yang berbeda pada setiap harinya yaitu setiap pukul 10.00-11.00 WITA dan 14.00-15.00 WITA. 


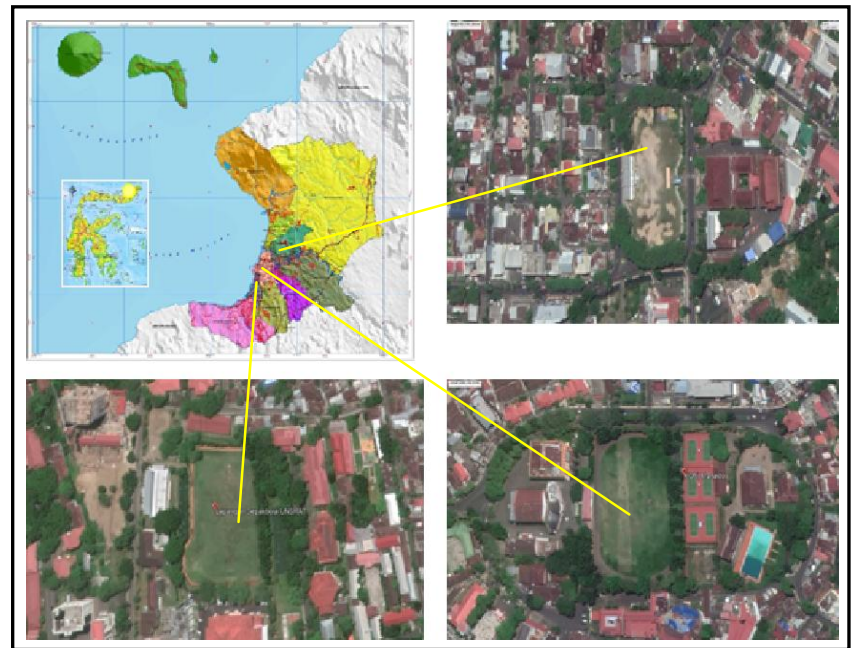

Sumber: CNES/Airbus, 2017

Gambar 1. Peta Lapangan Sparta Tikala, Lapangan KONI Manado dan Lapangan UNSRAT Manado (Figure 1. Map of Sparta Tikala Field, KONI Manado Field and UNSRAT Manado Field)

Alat yang digunakan dalam penelitian adalah : 1) Solar power meter untuk mengukur intensitas radiasi matahari $\left.\left(w a t t / \mathrm{m}^{2}\right), 2\right)$ Anemometer untuk mengukur kecepatan angin $(\mathrm{m} / \mathrm{s}), \quad 3)$ Thermo-Hygrometer digital untuk mengukur suhu $\left({ }^{\circ} \mathrm{C}\right)$ dan kelembaban udara $\left.(\%), 4\right)$ Thermometer infrared untuk mengukur suhu baju dan suhu tubuh $\left({ }^{\circ} \mathrm{C}\right)$, 5) Tripod sebagai dudukan alat, 6) Meteran dan Phi band untuk mengukur diameter dan luas tajuk pohon, 7) Microsoft exel untuk mengolah data.

Kuisioner responden mengambil data persepsi pengunjung terhadap kenyamanan termal di ketiga lokasi penelitian. Selain itu data yang dikumpulkan ialah suhu badan dan suhu pakaian yang bertujuan untuk menghitung kenyamanan termal responden. Mengenai persepsi kenyamanan termal menggunakan pola skala kenyamanan termal Gagge \& Berglund yang mempunyai skala dari $0-4$.

\section{Analisis Data}

Analisis data yang digunakan untuk iklim mikro ialah ialah analisis program surfur 15. Sedangkan untuk melihat kenyamanan termal di ketiga lokasi tersebut menggunakan Indeks DISC dari Fanger (1970) dalam Sangkertadi (2013) dengan rumus:

$$
\begin{aligned}
\text { DISC }= & 3.9338 \text { Mcut }+0.0158 \text { Ds }-0.3348 \quad \text { (1) } \\
& \text { dimana, DISC adalah Discomfort Scale }
\end{aligned}
$$
yang mempunyai indeks dari 0 - 4 dan Mcut adalah Persentase perbandingan antara luas kulit basah karena keringat terhadap luas kulit total, (\%) serta Ds adalah Debit atau volume keringat, (g/h). Perhitungan Mcut dan Ds pada indeks DISC didapat melalui beberapa tahap perhitungan.

\section{HASIL DAN PEMBAHASAN}

\section{Kondisi Iklim Mikro Suhu Udara}

Gambar 3 menunjukkan penyebaran suhu di Lapangan Tikala, yang mana gambar disebelah kiri merupakan suhu pada pukul 10.00-11.00 dan kanan 13.00-14.00. dapat dilihat bahwa warna merah menunjukkan suhu yang tinggi di Lapangan Tikala. Mulanya pukul 10.00-11.00 penyebarannya suhu tinggi masih sekitar tengah lapangan tetapi mulai melebar dan meluas hampir ke pinggir lapangan pada pukul 13.00-14.00.

Gambar 4 memperlihatkan suhu di Lapangan KONI Sario, yang mana pada pukul 10.00-11.00 suhu tinggi berada di tengah lapangan dan di pinggir lapangan suhunya lebih rendah. Pukul 13.00-14.00 di Lapangan KONI suhu di tengah lapangan mulai meningkat yang diikuti suhu di pinggir lapangan. 


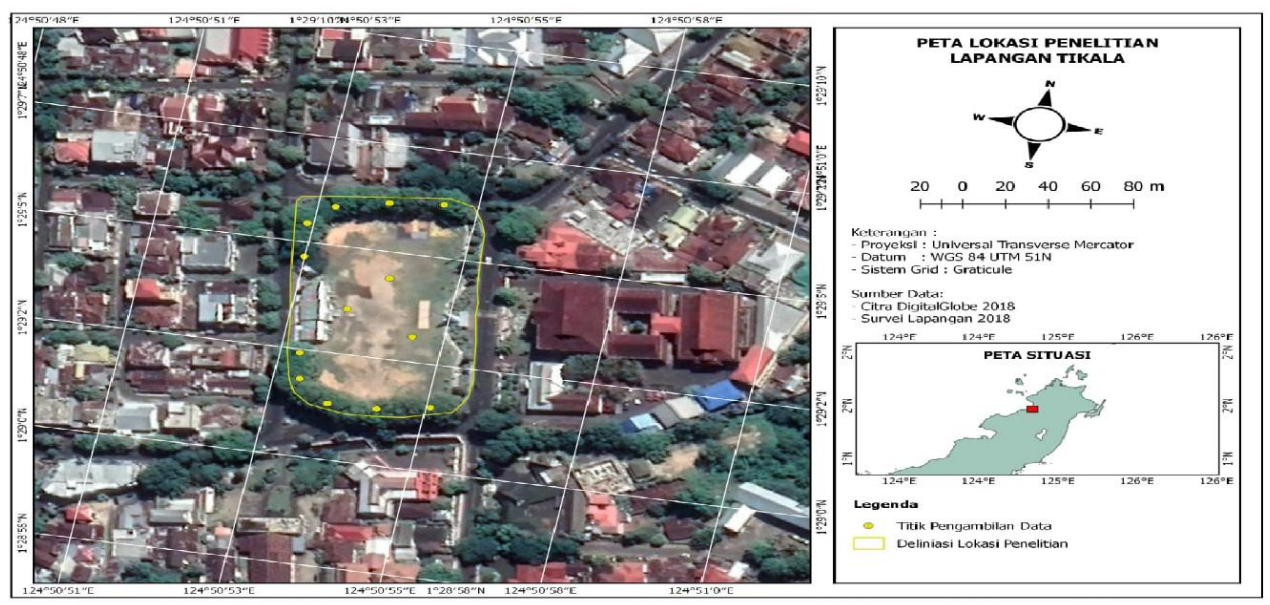

Lapangan Tikala, Manado

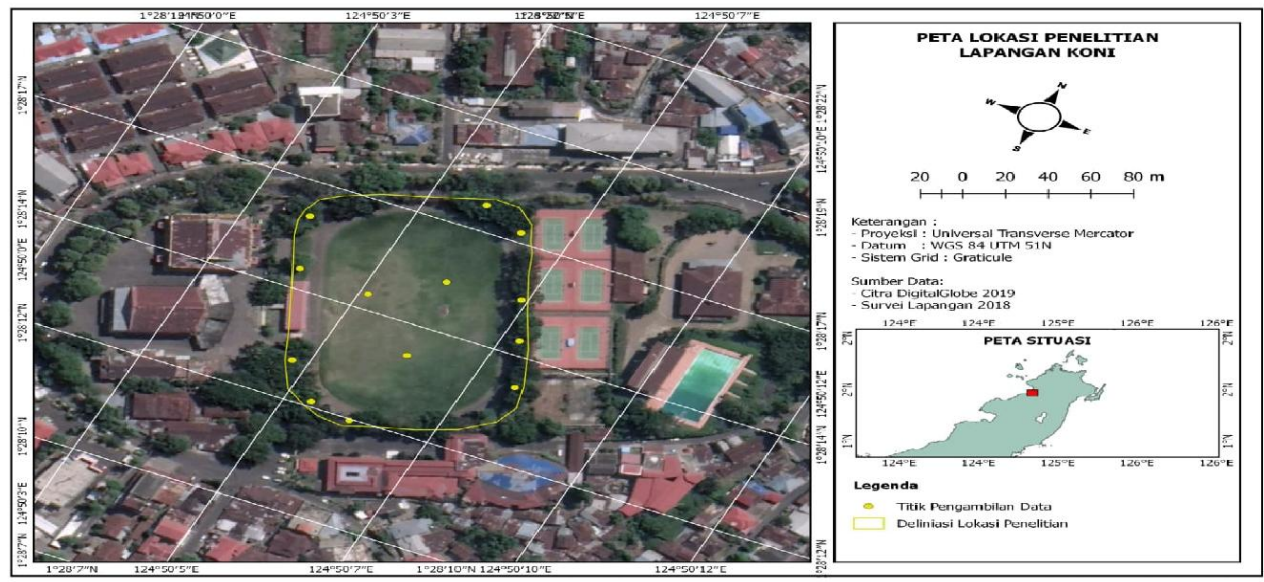

Lapangan KONI Manado

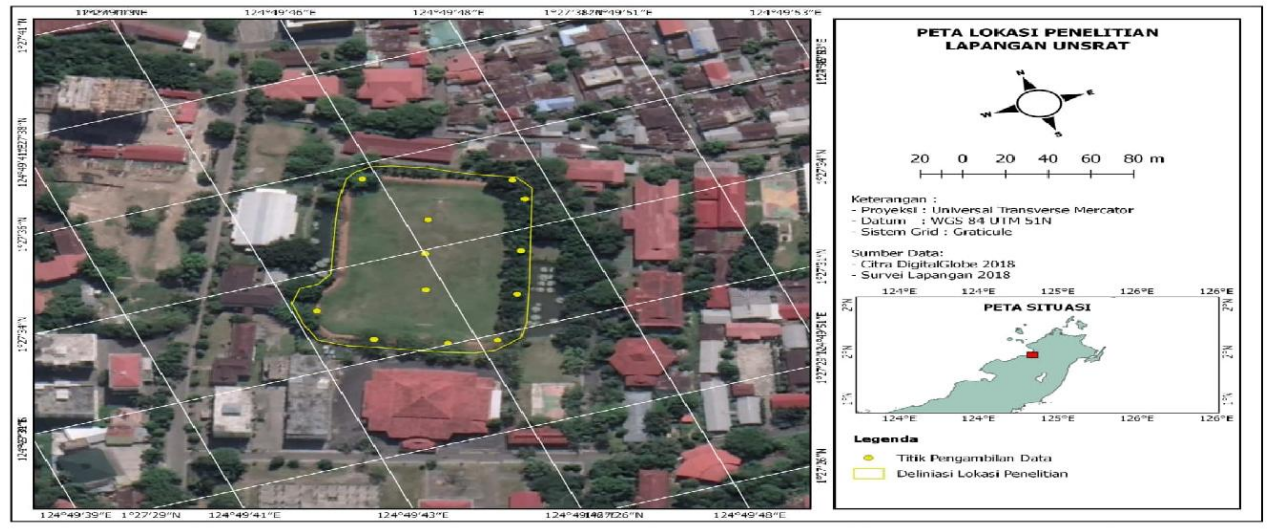

Lapangan UNSRAT

Sumber: Citra Digital Globe, 2018

Gambar 2. Peta Pengambilan Data

(Figure 2. Data Retrieval Map) 
Gambar 5 menunjukkan penyebaran suhu dari Lapangan UNSRAT. Pada pukul 10.00-11.00 menunjukkan tengah lapangan sampai disisi kiri lapangan UNSRAT mempunyai suhu yang tinggi, sedangkan pada sisi kanan lapangan mempunyai suhu yang lebih rendah dibandingkan sisi kanan. Hal ini dikarenakan vegetasi yang berada disisi lapangan masih muda dan luasan tajuknya lebih kecil dibandingkan disisi sebelah kanan. Suhu yang rendah di sisi kanan lapangan pada pukul 10.0011.00 dikarenakan terdapat kolam yang mempengaruhi suhu di sisi kanan Lapangan. Selain itu sudut datang matahari pada pukul 10.00-11.00 mempengaruhi sisi sebelah kanan lapangan.

Pada pukul 13.00-14.00 di Lapangan UNSRAT menunjukkan suhu tertinggi berada pada tengah lapangan dan pinggir lapangan suhunya menjadi lebih rendah dibandingkan dengan tengah lapangan

\section{Kelembaban Udara}

Gambar 6 menunjukkan kelembaban di Lapangan Tikala, gambar bagian atas menunjukkan kelembaban pada pukul 10.00-11.00. Tengah lapangan pukul 10.00-11.00 kelembaban begitu rendah dibandingkan berada di pinggir lapangan, hal itu dapat dilihat dari warna skala yang berwarna kecokelatan. Sedangkan pinggir lapangan yang berwarna biru tua mempunyai kelembaban yang tinggi dibanding di tengah lapangan hal tersebut terjadi karna di pinggir lapangan terdapat pohon peneduh. Salah satu sisi pada pinggir lapangan memilki kelembaban yang rendah, hal tersebut terjadi karna sisi lapangan tersebut tidak ditumbuhi oleh pohon peneduh.

Hal yang sama juga terjadi pada pukul 13.00-14.00 (gambar 6 bagian atas) kelembaban makin berkurang di tengah lapangan dibandingkan pukul 10.00-11.00 tetapi pada sisi lapangan tetap memiliki kelembaban yang tinggi.

Gambar 7 memperlihatkan kelembaban di Lapangan KONI Manado. Pada pukul 10.00-11.00 (gambar 7 bagian atas) menunjukkan tengah lapangan memiliki kelembaban yang rendah, sedangkan kelembaban yang tinggi berada pada pinggir lapangan yang ditumbuhi oleh pohon peneduh. Tetapi, memasuki pukul 13.00-14.00 (gambar 7 bagian bawah) kelembaban di pinggir lapangan mulai berkurang, hal ini dapat dilihat dari warna skala peta.

Gambar 8 memperlihatkan kelembaban di sekitar Lapangan UNSRAT pada pukul 10.00-11.00 (gambar 8 bagian atas) kelembaban yang paling rendah berada di tengah lapangan dan pada sisi kiri lapangan juga memiliki kelembaban yang rendah tetapi tidak seperti yang berada di tengah lapangan. Hal yang berbeda terjadi di sisi lapangan sebelah kanan, yang mana sisi lapangan tersebut memiliki kelembaban yang tinggi. Kemungkinan hal yang terjadi di sisi lapangan kiri pada pukul 10.00-11.00 dipengruhi oleh sudut datang matahari dan kecepatan matahari.

Kelembaban yang berada pada pukul 13.00-14.00 (gambar 8 bagian bawah) kelembaban terendah berada di tengah lapangan lalu pada pinggir lapangan memiliki kelembaban yang tinggi. Pohon peneduh yang tumbuh di pinggir lapangan membuat kelembaban menjadi tinggi dibanding di tengah lapangan.

\section{Radiasi Matahari}

Gambar 9 menunjukkan besar radiasi matahari yang berada di Lapangan Tikala. Pukul 10.00-11.00 (gambar 9 bagian atas) memperlihatkan radiasi matahari terbesar berada di tengah lapangan, yang dapat dilihat dengan skala berwarna merah, sedangkan sisi-sisi lapangan memiliki radiasi yang rendah tetapi sisi yang menghadap kantor walikota memikili radiasi yang rendah.

Pada pukul 13.00-14.00 (gambar 9 bagian bawah) radiasi semakin meningkat, peningkatan terjadi di sisi lapangan yang berada di depan kantor walikota.

Gambar 10 memperlihatkan besarnya radiasi matahari yang berada di Lapangan KONI. Pada pukul 10.00-11.00 (gambar 10 bagian atas) radiasi tertinggi terdapat di tengah lapangan dan radiasi semakin rendah di pinggir lapangan. Pukul 13.00-14.00 (gambar 10 bagian bawah) radiasi matahari mulai meningkat di tengah lapangan, yang dapat dilihat dari perubahan warna yang semakin merah. 
Gambar 11 memperlihatkan radiasi yang berada di Lapangan UNSRAT. Pukul 10.00-11.00 (gambar 11 bagian atas) radiasi terbesar berada di tengah lapangan dan mulai berkurang di pinggir lapangan. Hal yang sama terjadi pada pukul 13.0014.00 (gambar 11 bagian bawah) tetapi terlihat bahwa besarnya radiasi matahari sedikit berkurang, hal tersebut terjadi karena terdapat awan yang sedikit menutupi area Lapangan UNSRAT sehinggah radiasi matahari tidak sepenuhnya masuk ke lapangan.

\section{Kecepatan Angin}

Gambar 12 memperlihatkan kecepatan angin yang berada di Lapangan Tikala. Pukul 10.00-11.00 (gambar 12 sebelah kiri) kecepatan angin yang tinggi hampir terdapat di seluruh lapangan, hanya beberapa titik saja yang kecepatan anginnya rendah. Hal berbeda terjadi pada pukul 13.00-14.00 (gambar 12 sebelah kanan), kecepatan angin mulai rendah dibandingkan pada ukul 10.00-11.00.

Gambar 13 menunjukkan kecepatan angin di Lapangan KONI Manado. Pada pukul 10.0011.00 (gambar 13 bagian atas) kecepatan angin ber-hembus kencang hampir di seluruh area lapangan tetapi pada sisi lapangan yang berdekatan tribun kecepatan angin tidak terlalu tinggi. Pukul 13.00-14.00 kecepatan angin mulai berkurang, terutama di daerah tengah lapangan dan sisi lapangan yang semula kecepatan anginnya paling tinggi pada pukul 10.00-11.00.
Gambar 14 memperlihatkan kecepatan angin di Lapangan UNSRAT. Pada pukul 10.0011.00 (gambar 14 bagian atas) kecepatan angin paling tinggi berada di salah satu sisi lapangan tetapi mulai turun bertahap ke sisi lapangan yang dekat dengan kolam Fakultas MIPA UNSRAT. Pukul 13.00-14.00 (gambar 14 bagian bawah) menunjuk-kan kecepatan angin mulai berkurang di seluruh lapangan, terutama yang kecepatan anginnya paling besar pada pukul 10.00-11.00. Kecepatan angin tertinggi hanya terdapat di beberapa titik saja.

\section{Kenyamanan Termal}

Persentase kenyamanan termal dilihat berdasarkan 2 cara yaitu berdasarkan iklim mikro dan berdasarkan persepsi kenyamanan dari pengunjung pada ketiga tempat tersebut. Dapat dilihat Tabel 1 dan 2 menunjukkan persentase kenyamanan termal berdasarkan perhitungan iklim mikro pada pukul 10.00-11.00 dan 13.00-14.00, untuk kedua waktu tersebut lokasi UNSRAT merupakan lokasi ternyaman diantara ketiga lokasi tersebut.

Tabel 3 dan 4 menunjukkan kenyamanan berdasarkan persepsi pengunjung pada pukul 10.00-11.00 dan 13.00-14.00. Pada Tabel 3 dan 4 menunjukkan bahwa Tikala merupakan tempat paling nyaman diantara ketiga lokasi, sedangkan KONI merupakan tempat yang peliang tidak nyaman diantara ketiga lokasi.

Tabel 1. Persentase Kenyamanan Responden Berdasarkan Pengukuran Iklim Mikro pada pukul 10.00-11.00

(Table 1. Respondents' Comfort Percentage Based on Micro Climate Measurement at 10:00 to 11:00 am)

\begin{tabular}{ccccccc}
\hline & \multicolumn{3}{c}{ TIKALA } & \multicolumn{2}{c}{ KONI } & \multicolumn{2}{c}{ UNSRAT } \\
\hline & $\mathrm{n}$ & $\%$ & $\mathrm{n}$ & $\%$ & $\mathrm{n}$ & $\%$ \\
$\mathrm{~N}$ & 19 & 63,33 & 21 & 70,00 & 28 & 93,33 \\
ATN & 10 & 33,33 & 8 & 26,67 & 2 & 6,67 \\
TN & 1 & 3,33 & 0 & 0,00 & 0 & 0,00 \\
STN & 0 & 0 & 1 & 3,33 & 0 & 0,00 \\
TDD & 0 & 0 & 0 & 0,00 & 0 & 0,00 \\
TOTAL & 30 & 100,00 & 30 & 100,00 & 30 & 100,00 \\
\hline
\end{tabular}


Eugenia Volume 24 No. 2 Juni 2018

Tabel 2. Persentase Kenyamanan Responden Berdasarkan Pengukuran Iklim Mikro pada pukul 13.00-14.00

(Table 2. Respondents' Comfort Percentage Based on Micro Climate Measurement at 13.00-14.00 pm)

\begin{tabular}{ccccccc}
\hline & \multicolumn{2}{c}{ TIKALA } & \multicolumn{2}{c}{ KONI } & \multicolumn{2}{c}{ UNSRAT } \\
\hline & $\mathrm{n}$ & $\%$ & $\mathrm{n}$ & $\%$ & $\mathrm{~N}$ & $\%$ \\
$\mathrm{~N}$ & 1 & 3,33 & 6 & 20,00 & 24 & 80,00 \\
ATN & 27 & 90,00 & 24 & 80,00 & 5 & 16,67 \\
TN & 2 & 6,67 & 0 & 0,00 & 0 & 0,00 \\
STN & 0 & 0 & 0 & 0,00 & 0 & 0,00 \\
TDD & 0 & 0 & 0 & 0,00 & 1 & 3,33 \\
TOTAL & 30 & 100,00 & 30 & 100,00 & 30 & 100,00 \\
\hline
\end{tabular}

Tabel 3. Persentase Kenyamanan Responden Berdasarkan Hasil Pernyataan Responden pada pukul 10.0011.00

(Table 3. Respondents' Comfort Percentage Based on the Respondent's Statement at 10:00 to 11:00 am)

\begin{tabular}{ccccccc}
\hline & \multicolumn{2}{c}{ TIKALA } & \multicolumn{2}{c}{ KONI } & \multicolumn{2}{c}{ UNSRAT } \\
\hline & $\mathrm{n}$ & $\%$ & $\mathrm{n}$ & $\%$ & $\mathrm{n}$ & $\%$ \\
$\mathrm{~N}$ & 22 & 73,33 & 10 & 33,33 & 19 & 63,33 \\
ATN & 2 & 6,67 & 7 & 23,33 & 4 & 13,33 \\
TN & 6 & 20,00 & 11 & 36,67 & 6 & 20,00 \\
STN & 0 & 0,00 & 2 & 6,67 & 1 & 3,33 \\
TDD & 0 & 0,00 & 0 & 0,00 & 0 & 0,00 \\
TOTAL & 30 & 100,00 & 30 & 100,00 & 30 & 100,00 \\
\hline
\end{tabular}

Tabel 4. Persentase Kenyamanan Responden Berdasarkan Hasil Pernyataan Responden pada pukul 13.0014.00

(Table 4. Respondents' Comfort Percentage Based on the Respondent's Statement at 13:00 to 14:00 pm)

\begin{tabular}{ccccccc}
\hline & \multicolumn{2}{c}{ TIKALA } & \multicolumn{3}{c}{ KONI } & \multicolumn{2}{c}{ UNSRAT } \\
\hline & $\mathrm{n}$ & $\%$ & $\mathrm{n}$ & $\%$ & $\mathrm{n}$ & $\%$ \\
$\mathrm{~N}$ & 18 & 60,00 & 0 & 0,00 & 17 & 56,67 \\
ATN & 5 & 16,67 & 5 & 16,67 & 2 & 6,67 \\
TN & 5 & 16,67 & 19 & 63,33 & 10 & 33,33 \\
STN & 2 & 6,67 & 6 & 20,00 & 1 & 3,33 \\
TDD & 0 & 0,00 & 0 & 0,00 & 0 & 0,00 \\
TOTAL & 30 & 100,00 & 30 & 100,00 & 30 & 100,00 \\
\hline
\end{tabular}

Keterangan :

$\begin{array}{ll}\mathrm{N} & \text { : Nyaman } \\ \text { ATN } & : \text { Agak Tidak Nyaman } \\ \text { TN } & : \text { Tidak Nyaman } \\ \text { STN } & : \text { Sangat Tidak Nyaman } \\ \text { TDD } & : \text { Tidak Dapat Ditoleransi } \\ \mathrm{n} & : \text { Jumlah Responden }\end{array}$



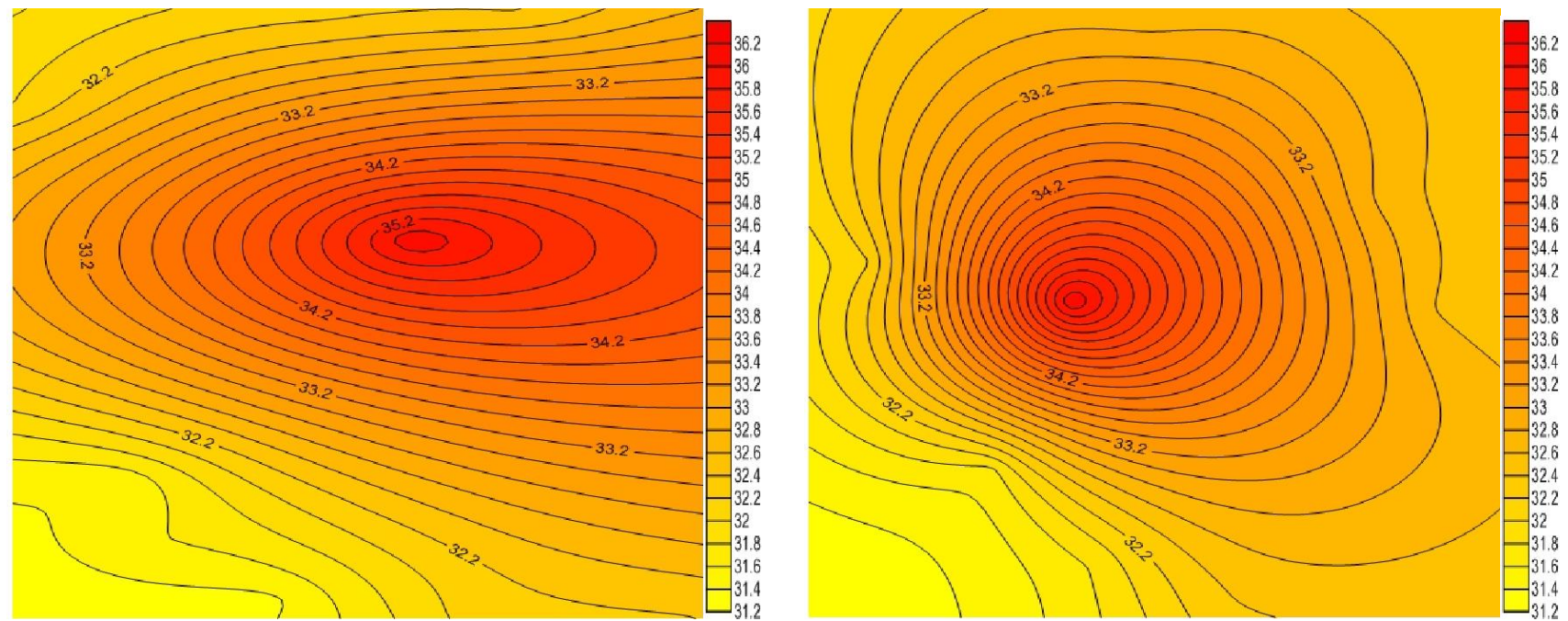

Gambar 3. Pengukuran Suhu Udara di Lapangan Tikala Pukul 10.00-11.00 dan 13.00-14.00

(Figure 3. Air Temperature measurement in Tikala Field at 10:00 to 11:00 am and 01:00 to 02:00 pm)
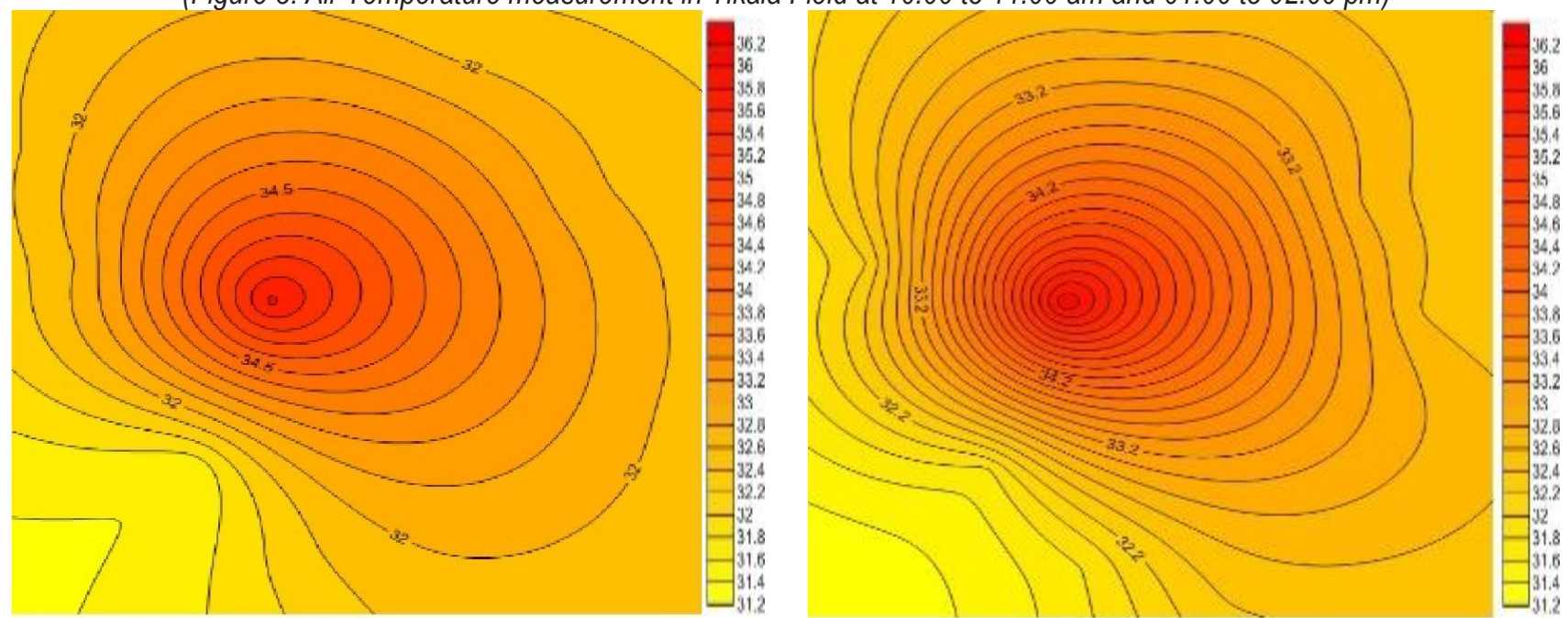

Gambar 4. Pengukuran Suhu Udara di Lapangan KONI Pukul 10.00-11.00 dan 13.00-14.00

(Figure 4. Air Temperature measurement in KONI Field at 10:00 to 11:00 am and 01:00 to 02:00 pm)
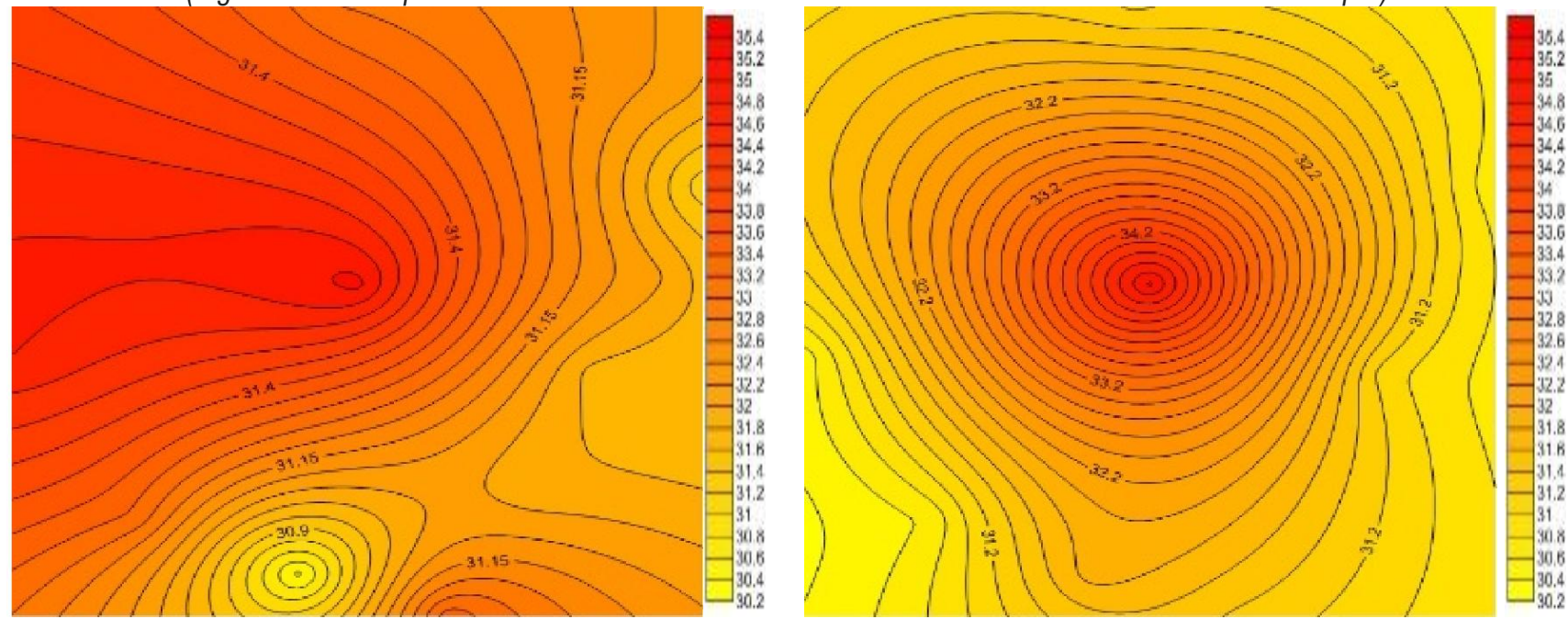

Gambar 5. Pengukuran Suhu Udara di Lapangan UNSRAT Pukul 10.00-11.00 dan 13.00-14.00. (Figure 5. Air Temperature measurement in UNSRAT Field at 10:00 to 11:00 am and 01:00 to 02:00 pm) 

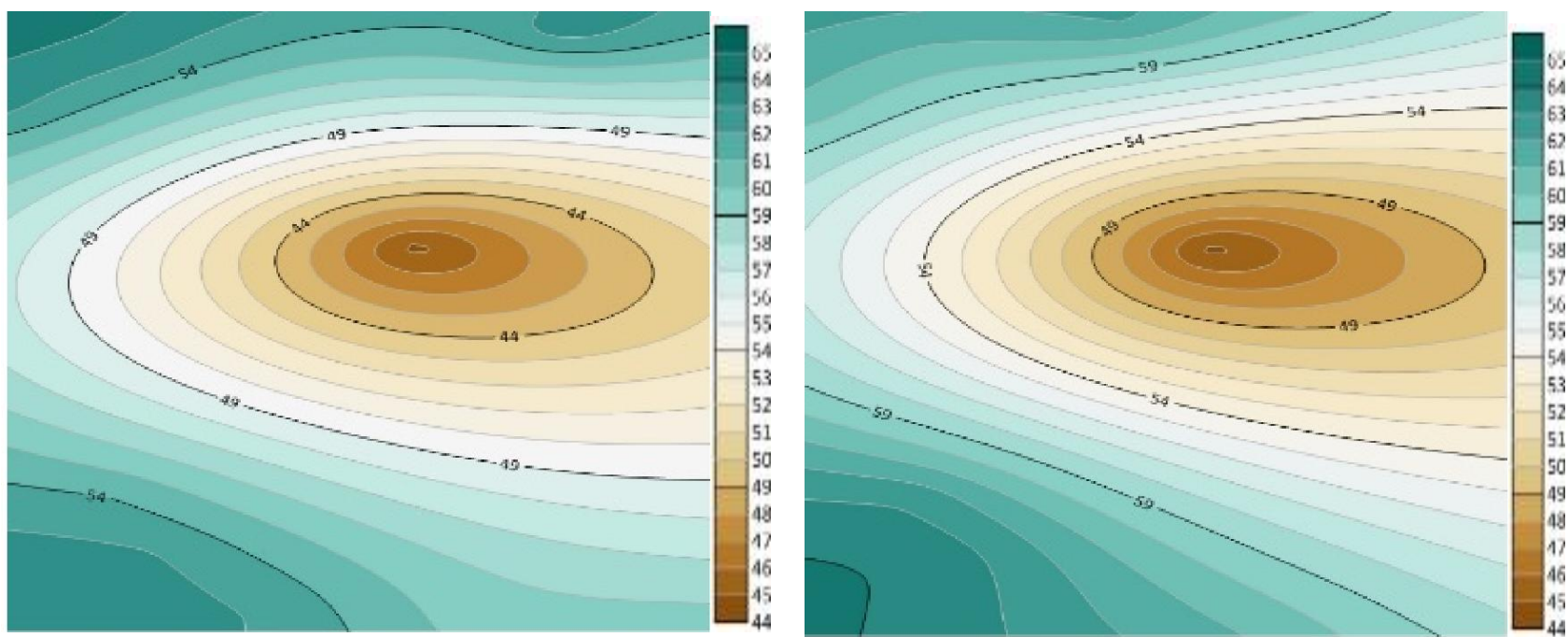

Gambar 6. Pengukuran Kelembaban Udara di Lapangan Tikala Pukul 10.00-11.00 dan 13.00-14.00

(Figure 6. Measurement of air humidity in Tikala Field at 10:00 to 11:00 am and 01:00 to 02:00 pm)
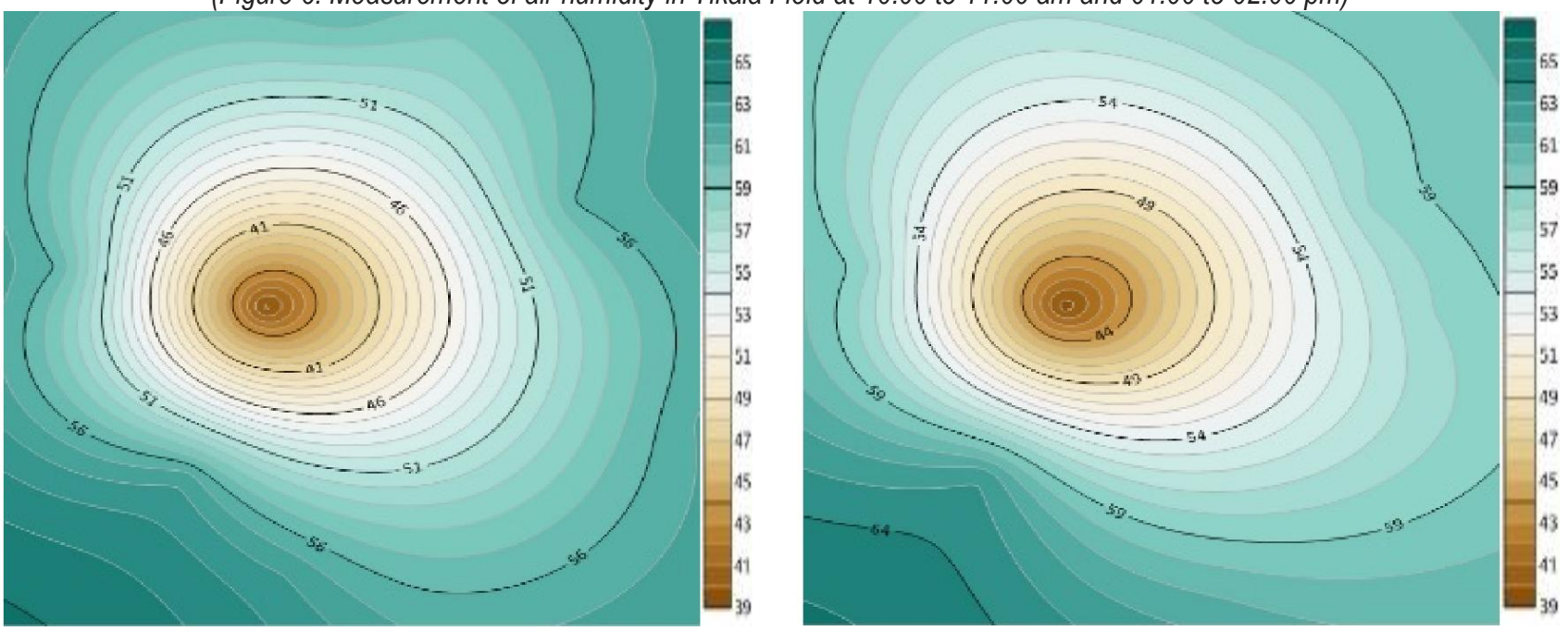

Gambar 7. Pengukuran Kelembaban Udara di Lapangan KONI Pukul 10.00-11.00 dan 13.00-14.00

(Figure 7. Measurement of air humidity in KONI Field at 10:00 to 11:00 am and 01:00 to 02:00 pm)

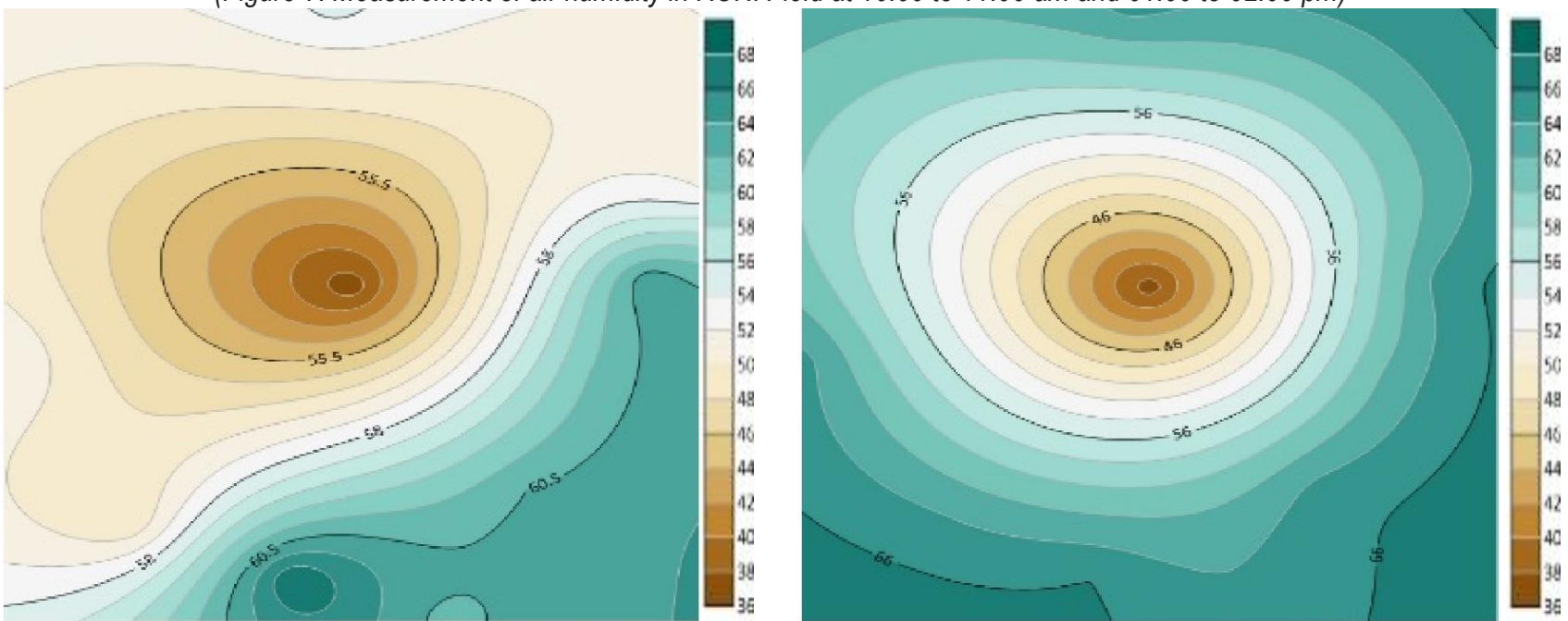

Gambar 8. Pengukuran Kelembaban Udara di Lapangan UNSRAT Pukul 10.00-11.00 dan 13.00-14.00

(Figure 8. Measurement of air humidity in UNSRAT Field at 10:00 to 11:00 am and 01:00 to 02:00 pm) 

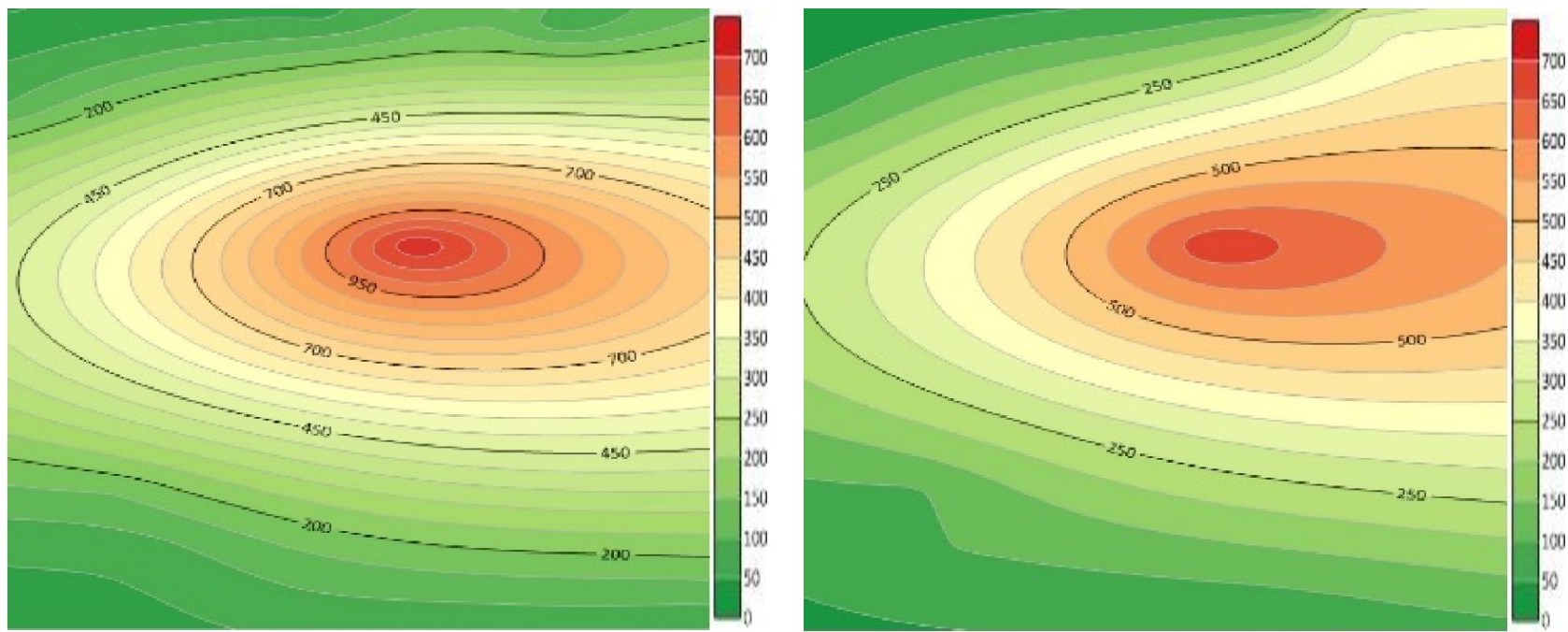

Gambar 9. Pengukuran Radiasi Matahari di Lapangan Tikala Pukul 10.00-11.00 dan 13.00-14.00 (Figure 9. Measurement of Solar Radiation in Tikala Field at 10:00 to 11:00 am and 01:00 to 02:00 pm)
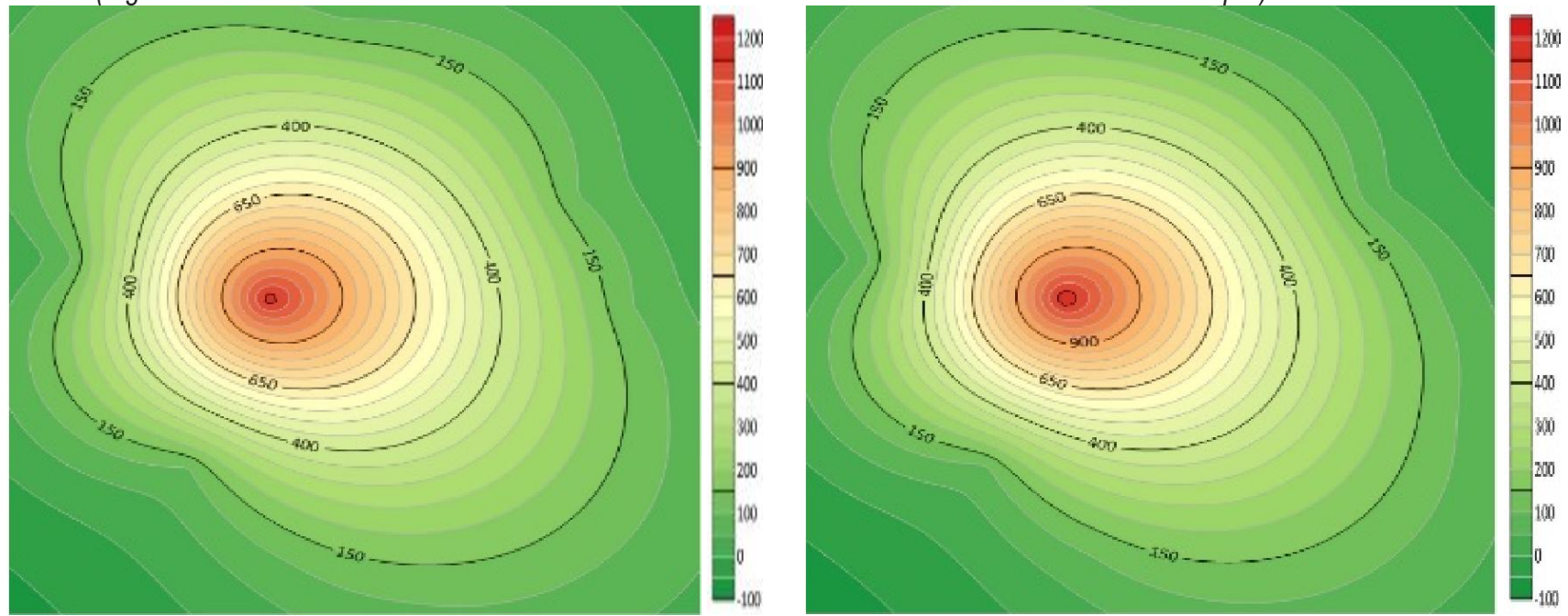

Gambar 10. Pengukuran Radiasi Matahari di Lapangan KONI Pukul 10.00-11.00 dan 13.00-14.00

(Figure 10. Measurement of Solar Radiation in KONI Field at 10:00 to 11:00 am and 01:00 to 02:00 pm)
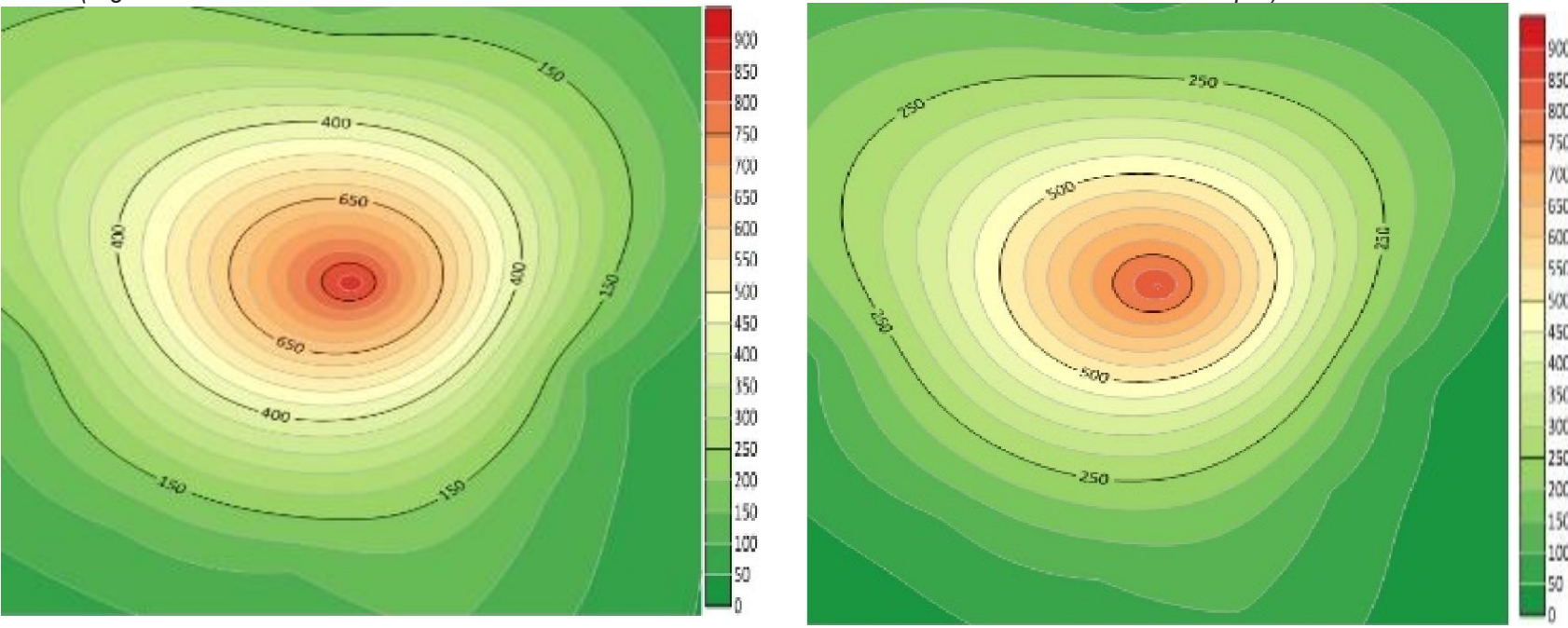

Gambar 11. Pengukuran Radiasi Matahari di Lapangan UNSRAT Pukul 10.00-11.00 dan 13.00-14.00 (Figure 11. Measurement of Solar Radiation in UNSART Field at 10:00 to 11:00 am and 01:00 to 02:00 pm) 

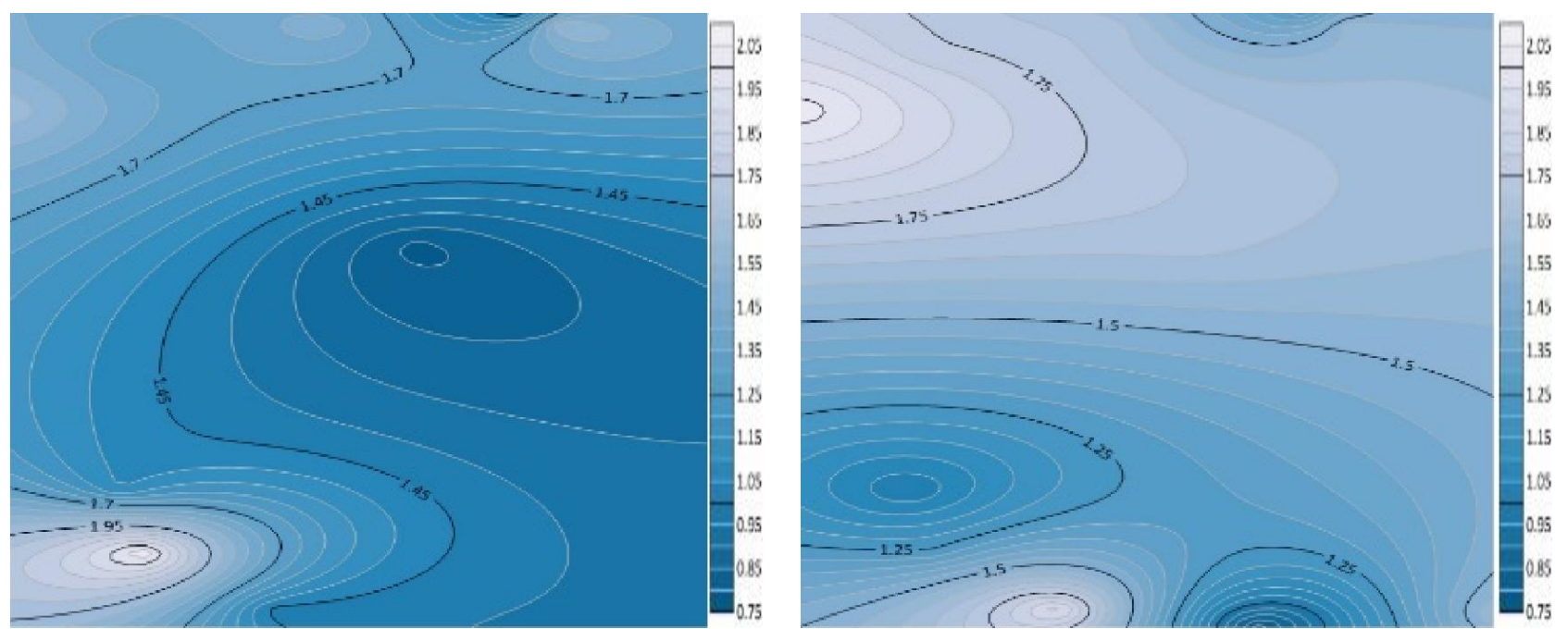

Gambar 12. Pengukuran Kecepatan Angin di Lapangan Tikala Pukul 10.00-11.00 dan 13.00-14.00 (Figure 12. Measurement of Wind Speed in Tikala Field at 10:00 to 11:00 am and 01:00 to 02:00 pm)
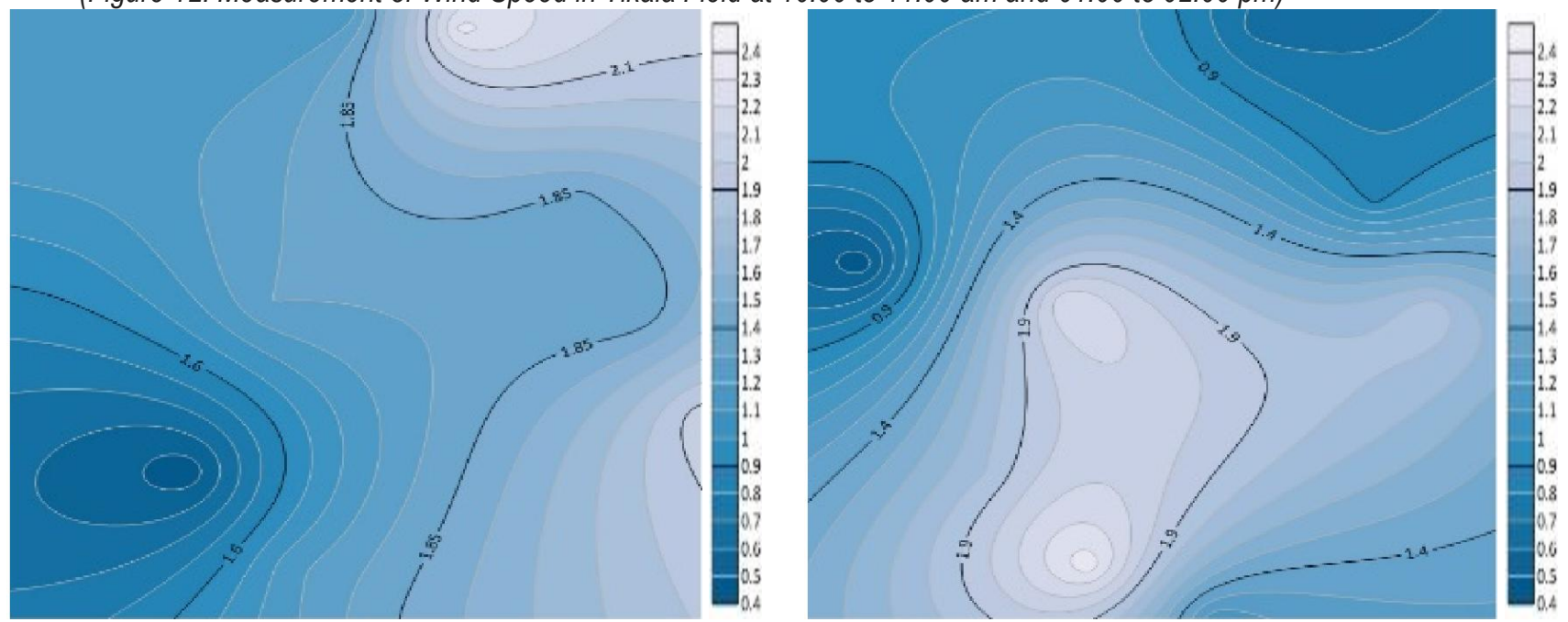

Gambar 13. Pengukuran Kecepatan Angin di Lapangan KONI Pukul 10.00-11.00 dan 13.00-14.00 (Figure 13. Measurement of Wind Speed in KONI Field at 10:00 to 11:00 am and 01:00 to 02:00 pm)
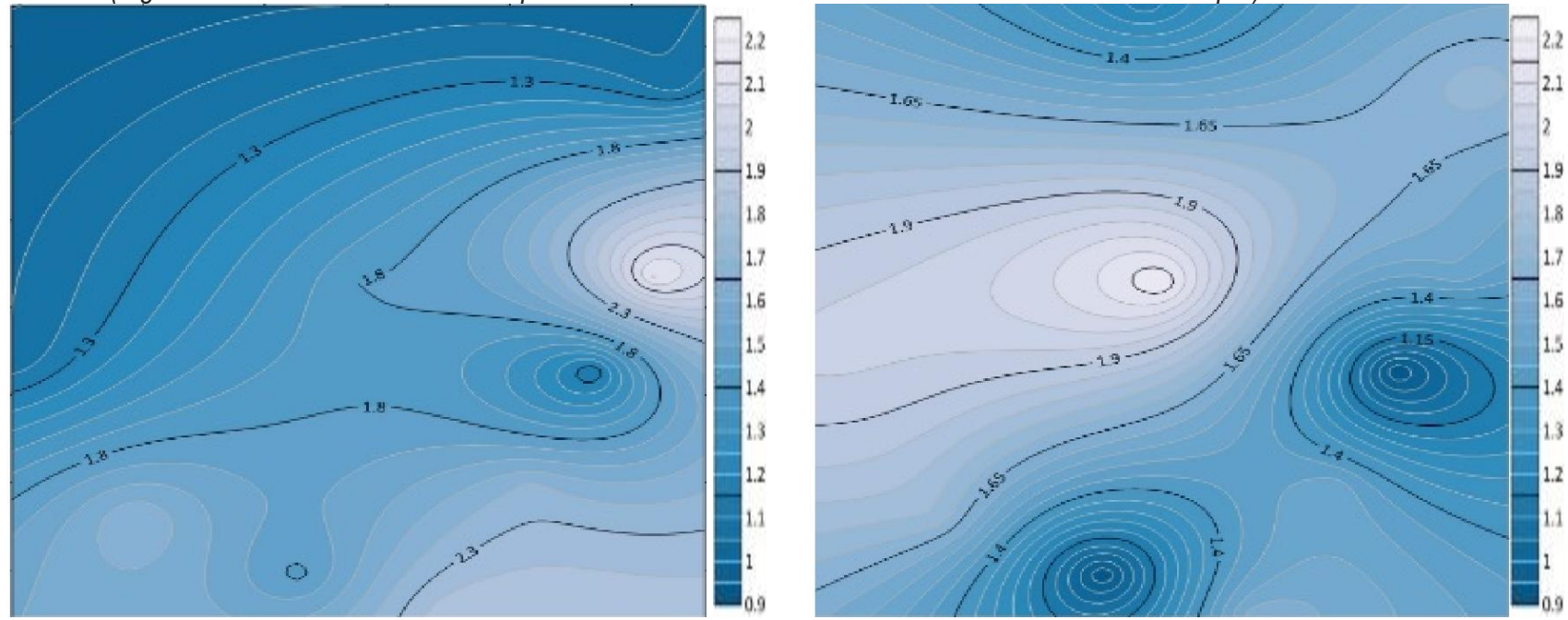

Gambar 14. Pengukuran Kecepatan Angin di Lapangan UNSRAT Pukul 10.00-11.00 dan 13.00-14.00 (Figure 14. Measurement of Wind Speed in UNSRAT Field at 10:00 to 11:00 am and 01:00 to 02:00 pm) 


\section{KESIMPULAN DAN SARAN}

\section{Kesimpulan}

Berdasarkan hasil penelitian didapatkan beberapa kesimpulan yaitu : 1) Terdapat perbedaan iklim mikro pada ketiga lokasi pengamatan yaitu antara luar dan dalam naungan pohon dan antar waktu. Perbedaan terjadi dapat diakibatkan oleh faktor tingkat perkerasan suatu tempat, kawasan terbangun sekitar RTH, jenis pohon, dan luas tajuk pohon, 2) Terdapat perbedaan kenyamanan termal pada 2 (dua) waktu yang berbeda, dan Lapangan UNSRAT merupakan tempat paling nyaman.

\section{Saran}

Perlu adanya perhatian pemerintah terkait dalam melakukan pengelolaan RTH (Ruang Terbuka Hijau) untuk menciptakan iklim mikro yang sesuai dan baik, seperti pemilihan jenis vegetasi, jarak tanam, peningkatan vegetasi dari segi struktur dan komposisi, serta mencari solusi dalam mengatasi pantulan dan penyerapan radiasi matahari yang kuat dari perkerasan jalan dan bangunan sekitar.

\section{DAFTAR PUSTAKA}

Badan Pusat Statistik (BPS). 2016. Indonesia Dalam Angka. Diakses dari https://www.bps.go.id/. Diakses pada tanggal 31 oktober 2016.

Budihardjo, E.. 2015. Kota dan Lingkungan Pendekatan Baru Masyarakat Berwawasan Ekologi. LP3ES Indonesia. Jakarta.
Filani, R.. 2013. Perilaku Penataan dan Pengelolaan Ruang Terbuka Hijau di Kota Pontianak. Jurnal Administrasi Negara, 2(1):1-9.

Idham, N. C.. 2016. Arsitektur dan Kenyamanan Termal. Andi Yogyakarta. Yogyakarta.

Irwan, Z. D.. 2008. Tantangan Lingkungan dan Lansekap Hutan Kota. Bumi Aksara. Jakarta.

Joga, N. dan I. Ismaun. 2011. RTH $30 \%$ Resolusi Kota Hijau. PT. Gramedia Pusaka Utama. Jakarta.

Obi, N. I.. 2014. The Influence of Vegetation on Microclimate in Hot Humid Tropical Environment-A Case of Enugu Urban. International Journal of Energy and Environmental Research, 2(2):28-38.

Anonim. 2008. Peraturan Menteri Pekerjaan Umum, No: 05/PRT/M/2008 tentang Pedoman Penyedia dan Pemanfaatan Ruang Terbuka Hijau Dikawasan Perkotaan. Republik Indonesia.

Sangkertadi. 2013. Kenyamanan Termis di Ruang Luar Beriklim Tropis Lembab. Alfabeta. Bandung. 